\title{
GLYCINE RECEPTOR: LIGHT MICROSCOPIC AUTORADIOGRAPHIC LOCALIZATION WITH $\left[{ }^{3} \mathrm{H}\right]$ STRYCHNINE ${ }^{1}$
}

\author{
MARCO A. ZARBIN, JAMES K. WAMSLEY, AND MICHAEL J. KUHAR ${ }^{2}$ \\ Departments of Neuroscience, Pharmacology and Experimental Therapeutics, Psychiatry, and the Behavioral Sciences, The Johns Hopkins \\ University School of Medicine, Baltimore, Maryland 21205
}

\begin{abstract}
Glycine receptors have been localized by autoradiography in the rat central nervous system (CNS) using $\left[{ }^{3} \mathrm{H}\right]$ strychnine. The gross distribution of receptors is in excellent accord with the distribution determined by filtration binding assays. Specifically, the density of glycine receptors is greatest in the gray matter of the spinal cord and decreases progressively in regions more rostral in the neuraxis. Glycine receptors were found to be associated with both sensory and motor systems in the CNS. Moreover, there is a striking correlation between areas of high strychnine binding site density and areas in which glycine has been found to be electrophysiologically active. Finally, the anatomic localization of strychnine binding sites may help explain many of the signs and symptoms of strychnine ingestion. For example, individuals consuming subconvulsive doses of strychnine frequently experience altered cutaneous and auditory sensation. We have localized strychnine receptors in areas of the acoustic system known to influence discriminative aspects of audition and in areas of the spinal cord and trigeminal nuclei which modulate discriminative aspects of cutaneous sensation. The alteration of visceral functions (e.g., blood pressure and respiratory rate) associated with strychnine ingestion may be accounted for in a similar manner.
\end{abstract}

Glycine is thought to be an important inhibitory neurotransmitter in the spinal cord and brainstem of the rat and other species (Aprison et al., 1976; Aprison and Werman, 1965; Aprison and Nadi, 1977; DeFeudis, 1977; Werman et al., 1966, 1967, 1968; Curtis et al., 1968). Strychnine is a highly specific antagonist of glycine in electrophysiological studies (Lodge et al., 1977; Curtis et al., 1976; Belcher et al., 1976; Game and Lodge, 1975; Tebecis and DiMaria, 1972; Tebecis, 1973). Young and Snyder $(1973,1974 \mathrm{a}, \mathrm{b})$ have defined conditions in which $\left[{ }^{3} \mathrm{H}\right]$ strychnine will bind to a site in brain tissue thought to be a component of the glycine receptor (GR). By using a generally applicable in vitro labeling light microscopic autoradiographic procedure (Young and Kuhar, 1979a), we have localized and mapped putative glycine receptors by examining the distribution of $\left[{ }^{3} \mathrm{H}\right]$ strychnine binding sites (SBS) in rat brain.

\footnotetext{
'We acknowledge the skillful technical assistance rendered by Ms. Anne Foard and Mrs. Naomi Taylor and thank Ms. Darlene Weimer and Mrs. Mary Flutka for their excellent clerical assistance. This work was supported by United States Public Health Service Grant MH25951. M. J. K. is the recipient of Research Career Development Type II Award MH00053. J. K. W. is supported by Grant NS15080 and M. A. Z. is supported by Grant GM07309, Medical Scientist Training Program.

${ }^{2}$ 'To whom correspondence should be addressed at Department of Neuroscience, Johns Hopkins University School of Medicine, $725 \mathrm{~N}$. Wolfe Street, Baltimore, MD 21205.
}

\section{Materials and Methods}

The autoradiographic method for localizing the receptors (Young and Kuhar, 1979a) involves the labeling of receptors by binding techniques in slide-mounted tissue sections and the generation of autoradiograms by the apposition of emulsion-coated coverslips. Additional details are as follows.

Tissue preparation. Male Sprague-Dawley rats (Madison, WI, 180 to $250 \mathrm{gm}$ ) were anesthetized with pentobarbital $(60 \mathrm{mg} / \mathrm{kg}$, i.p.) and perfused intracardially with 200 to $300 \mathrm{ml}$ of $0.1 \%$ formaldehyde (Fisher, Fair Lawn,

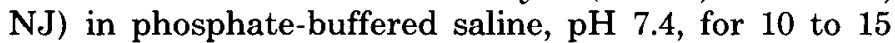
min. The slight fixation of the tissue was shown to have no apparent adverse effect on receptor binding. Subsequently, the brains and spinal cords were dissected rapidly from the animals, frozen onto microtome chucks, and stored in liquid nitrogen. The tissues were sectioned $(6$ to $10 \mu \mathrm{m})$ on a Harris cryostat microtome (Harris Manufacturing Co., North Billerica, MA), thaw-mounted onto acid-washed, subbed (gelatin and chrome alum) slides, and stored for at least 3 days to allow adhesion of the tissues to the slides. Material prepared in this way was stored for as long as 3 weeks at $-20^{\circ} \mathrm{C}$ with no detectable loss in receptor binding.

Receptor binding. Slide-mounted tissue sections were brought to room temperature and incubated at $4^{\circ} \mathrm{C}$ in $0.05 \mathrm{~m}$ sodium potassium phosphate buffer, $\mathrm{pH} 7.4$, containing $4 \mathrm{nM}\left[{ }^{3} \mathrm{H}\right]$ strychnine. $\left[{ }^{3} \mathrm{H}\right]$ Strychnine binding in 
the presence of $10^{-2} \mathrm{M}$ glycine was used to estimate nonspecific binding (binding unassociated with the synaptic strychnine receptor). Using these incubation conditions, Young and Snyder (1973) have demonstrated previously that $\left[{ }^{3} \mathrm{H}\right]$ strychnine binding is of high affinity, saturable, and stereospecific and has pharmacologic characteristics appropriate for the physiologic glycine receptor. After incubation, the slides were rinsed in sodium potassium phosphate buffer, $\mathrm{pH} 7.4$, dipped in a deionized distilled water rinse, and dried in a stream of dry, cool air for autoradiographic experiments. For biochemical estimates of $\left[{ }^{3} \mathrm{H}\right]$ strychnine binding, however, the tissues were not dried; rather, the tissue was wiped off of the slide using a Whatman GFB-3 filter (Whatman Ltd., England), dissolved in Formula 947 (New England Nuclear, Boston, MA), and subject to scintillation counting using a Isocop/300 (Searle Analytic, Inc., Des Plaines, IL) liquid scintillation counter. It is possible that substances present in the tissue sections (e.g., endogenous glycine) could interfere with $\left[{ }^{3} \mathrm{H}\right]$ strychnine binding. This possibility was examined in the following way. Tissue sections were preincubated in conditions known to promote the dissociation of glycine from its synaptic receptor. Since the binding of $\left[{ }^{3} \mathrm{H}\right]$ strychnine increased by 10 to $15 \%$ (over that observed without preincubation of the tissue sections), we felt that the possible inhibition by endogenous substances was small under these conditions, but the preincubation step was included in some experiments.

Autoradiography. Autoradiographic experiments were carried out as described previously (Young and Kuhar, 1979a, b; Palacios et al., 1980). The autoradiograms were developed for 1.5 or 3 months.

Slides were reviewed using a Zeiss Universal Microscope, a Leitz microscope, or an Olympus microscope. The latter two microscopes were used to photograph the autoradiograms. Previous studies (Young and Kuhar, 1979a) have shown that this autoradiographic technique is quantitative (grain density proportional to the time of exposure and tissue content of radioactivity). Grain densities were quantified using the Zeiss scope and an eyepiece equipped with a superimposed grid.

Chemicals. $\left[{ }^{3} \mathrm{H}\right]$ Strychnine $(13.2 \mathrm{Ci} / \mathrm{mmol})$ was purchased from Amersham (Amersham, England). All other compounds were obtained from commercial suppliers.

\section{Results}

Before generating autoradiograms, one must establish that the binding of radiolabeled ligand to the slidemounted tissue sections has the kinetic and pharmacologic characteristics associated with the physiologically relevant receptor. Moreover, one must define the experimental conditions in which the ratio of specific binding to nonspecific binding is maximal while the specific binding is still large enough to label a significant fraction of the total population of receptors. Accordingly, various kinetic and pharmacologic studies were carried out to define the incubation parameters and assess the relevance of the binding to tissue sections.

Kinetic analysis of $\left[{ }^{3} \mathrm{H}\right]$ strychnine binding. The rate of dissociation of strychnine binding was determined. Slide-mounted sections of rat spinal cord (9 to $12 \mathrm{sec}-$ tions/slide) were incubated in $4 \mathrm{~nm}\left[{ }^{3} \mathrm{H}\right]$ strychnine for 40 min at $4^{\circ} \mathrm{C}$. Some sections were incubated in a solution which contained $10^{-2} \mathrm{M}$ glycine as well in order to determine nonspecific binding. After the incubations, the tissue sections were transferred to buffer solutions at $4^{\circ} \mathrm{C}$, for various times in order to remove nonspecifically bound $\left[{ }^{3} \mathrm{H}\right]$ strychnine. The results of these experiments are shown in Figure 1. The nonspecific binding decreased to low levels by $5 \mathrm{~min}$ and was decreased further only slightly by longer rinsing times. The specific binding, defined as the difference between the total amount of $\left[{ }^{3} \mathrm{H}\right]$ strychnine bound and the amount of nonspecifically bound $\left[{ }^{3} \mathrm{H}\right]$ strychnine, decreased by $50 \%$ after roughly 5 $\mathrm{min}$. The ratio of specific to nonspecific binding increased from 0.49 to 2.60 as the dissociation time increased from 0 to $5 \mathrm{~min}$. The calculated dissociation constant was 0.089 $\mathrm{min}^{-1}$. The dissociation appeared monophasic, suggesting that a single population of receptors was labeled. Because a 5-min wash significantly reduced the nonspecific binding but still allowed a large fraction (50\%) of the specific binding to remain, 5-min wash times were employed in all of the following experiments.

The rate of association of $\left[{ }^{3} \mathrm{H}\right]$ strychnine with receptors in slide-mounted sections of rat spinal cord was examined. Slide-mounted tissue sections were incubated

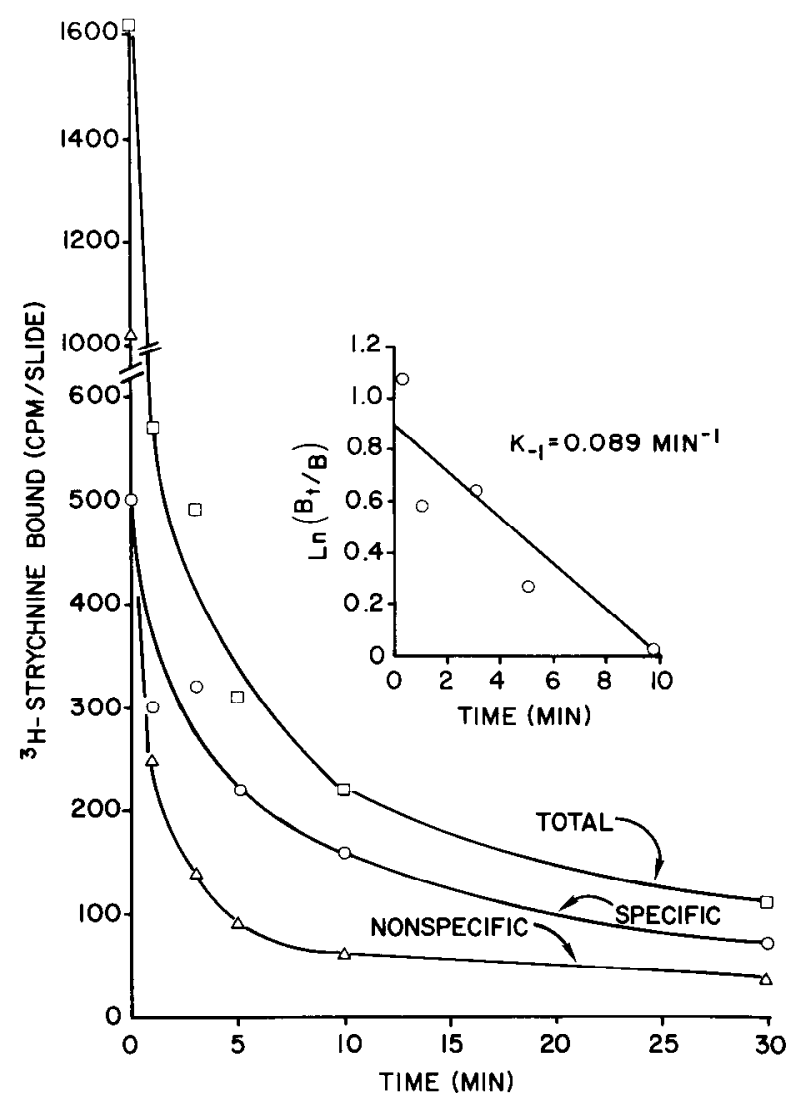

Figure 1. Time course of dissociation of $\left[{ }^{3} \mathrm{H}\right]$ strychnine binding (at $4^{\circ} \mathrm{C}$ ) from slide-mounted tissue sections. Nonspecific binding (defined as the binding of $\left[{ }^{3} \mathrm{H}\right]$ strychnine in the presence of $10 \mathrm{~mm}$ glycine) is represented as $\Delta$. Specific binding $(O)$ is obtained by subtracting nonspecific binding from total binding ( $\square$ ). The points are the average of four determinations with less than $15 \%$ difference among the samples. Inset shows the dissociation ratio of specific binding: $k_{-1}=0.089 \mathrm{~min}^{-1} . B_{t} /$ $B$, total binding/specific binding. 
with $4 \mathrm{nM}\left[{ }^{3} \mathrm{H}\right]$ strychnine for various times, rinsed for 5 min, and assayed for radioactivity. Nonspecific binding was roughly the same at all time points. The total binding and specific binding increased with time during the first $20 \mathrm{~min}$ of incubation, after which, there was no further significant increase (Fig. 2). Analysis of the association data revealed $k_{\text {obs }}$ of $0.117 \mathrm{~min}^{-1}$. Based on these observations, it seemed reasonable to utilize an incubation time of $20 \mathrm{~min}$, a time at which binding was at equilibrium.

The saturation kinetics of $\left[{ }^{3} \mathrm{H}\right]$ strychnine binding was examined in tissue sections (Fig. 3). Slide-mounted sections of rat spinal cord were incubated with varying concentrations of $\left[{ }^{3} \mathrm{H}\right]$ strychnine for $20 \mathrm{~min}$, rinsed in buffer $\left(\right.$ at $4^{\circ} \mathrm{C}$ ) for $5 \mathrm{~min}$, and assayed for their content of radioactivity. The specific binding of $\left[{ }^{3} \mathrm{H}\right]$ strychnine appeared to be maximal at concentrations of $\left[{ }^{3} \mathrm{H}\right]$ strychnine greater than $26 \mathrm{~nm}$. Hill plots of the saturation data revealed a Hill slope of 1.1 in good agreement with the results of Young and Snyder (1974a).

Using the data in Figures 1 and 2, a dissociation constant $\left(K_{D}=k_{-1} / k_{1}\right)$ was calculated to be $13 \mathrm{~nm}$. Scatchard analysis of the saturation data (Fig. 3) revealed a $K_{D}$ of $15 \mathrm{~nm}$ and a $B_{\max }$ of $232 \mathrm{fmol} / \mathrm{mg}$ of tissue. These data agree well with those reported for $\left[{ }^{3} \mathrm{H}\right]$ strychnine binding to membrane homogenates (Muller and Snyder, 1978), although they are slightly larger in magnitude. This could be due to differences in experimental procedures and to the presence of some endogenous glycine competing for binding. Also, the $K_{D}$ calculated from Figures 1 and 2 is very similar to that derived from the equilibrium data.

Pharmacologic specificity of $\left[{ }^{3} \mathrm{H}\right]$ strychnine binding.
Slide-mounted tissue sections of rat spinal cord were incubated with $4 \mathrm{~nm}\left[{ }^{3} \mathrm{H}\right]$ strychnine with and without varying concentrations of other compounds. The sections were rinsed and subjected to scintillation counting as described above. Glycine was the most potent displacer of $\left[{ }^{3} \mathrm{H}\right]$ strychnine binding followed by $\beta$-alanine and taurine (see Table I). Serine, proline, $\delta$-aminovaleric acid, and $\gamma$-aminobutyric acid (GABA) were minimally effective as displacers. These results are qualitatively and quantitatively in very good agreement with data derived from $\left[{ }^{3} \mathrm{H}\right]$ strychnine binding in membrane homogenates (Young and Snyder, 1973). Atropine and triprolidine also were found to be ineffective as displacers of $\left[{ }^{3} \mathrm{H}\right]$ strychnine (Table I).

Autoradiographic studies. Six-micrometer-thick sections of rat brain tissue were incubated with $4 \mathrm{nM}\left[{ }^{3} \mathrm{H}\right]$ strychnine (with or without $10^{-2} \mathrm{M}$ glycine) for $20 \mathrm{~min}$, rinsed for $5 \mathrm{~min}$, and dried. After the sections were processed for autoradiography, variations in grain density over different loci were observed and quantified (Table II). In general, autoradiographic grains were associated with the gray matter of the central nervous system (CNS), while only very low grain densities were noted over the white matter.

Spinal cord. The highest grain density observed in the rat CNS was associated with the gray matter of the spinal cord (Figs. 4 and 5). The labeling within this region, however, was not uniform. The highest grain densities in thoracic and cervical regions were observed in laminae II, III, V (lateral), and VII (dorsal). Lower grain densities were noted over laminae IV, V (medial), VII (ventromedial), VIII, IX, and X. The lowest density in the gray matter was observed over lamina I, while the funiculi

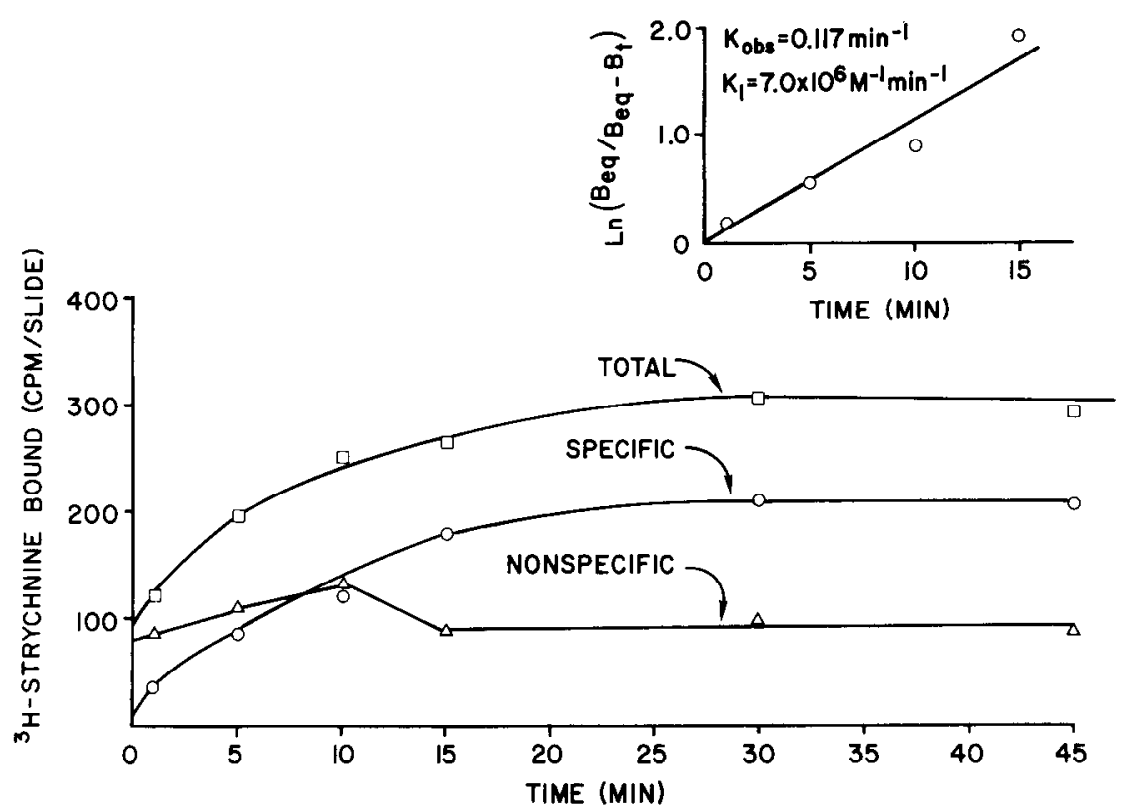

Figure 2. Time course of association of $\left[{ }^{3} \mathrm{H}\right]$ strychnine (at $4^{\circ} \mathrm{C}$ ) to slidemounted tissue sections. Specific binding $(\mathrm{O})$ is obtained by subtracting nonspecific binding $(\Delta)$, defined as binding of $\left[{ }^{3} \mathrm{H}\right]$ strychnine in the presence of $10 \mathrm{~mm}$ glycine, from total binding $(\square)$. The wash time for all observations was $5 \mathrm{~min}$ (at $4^{\circ} \mathrm{C}$ ). Each point is the average of two determinations which differed by less than $15 \%$. Inset shows the association binding kinetics: $k_{\text {nhs }}=$ $0.117 \mathrm{~min}^{-1} ; k_{1}=7.0 \times 10^{6} \mathrm{M}^{-1} \mathrm{~min}^{-1} . B_{\mathrm{eq}} / B_{\mathrm{eq}}-B_{\ell}$, binding at equilibrium/ binding at equilibrium - total binding. 


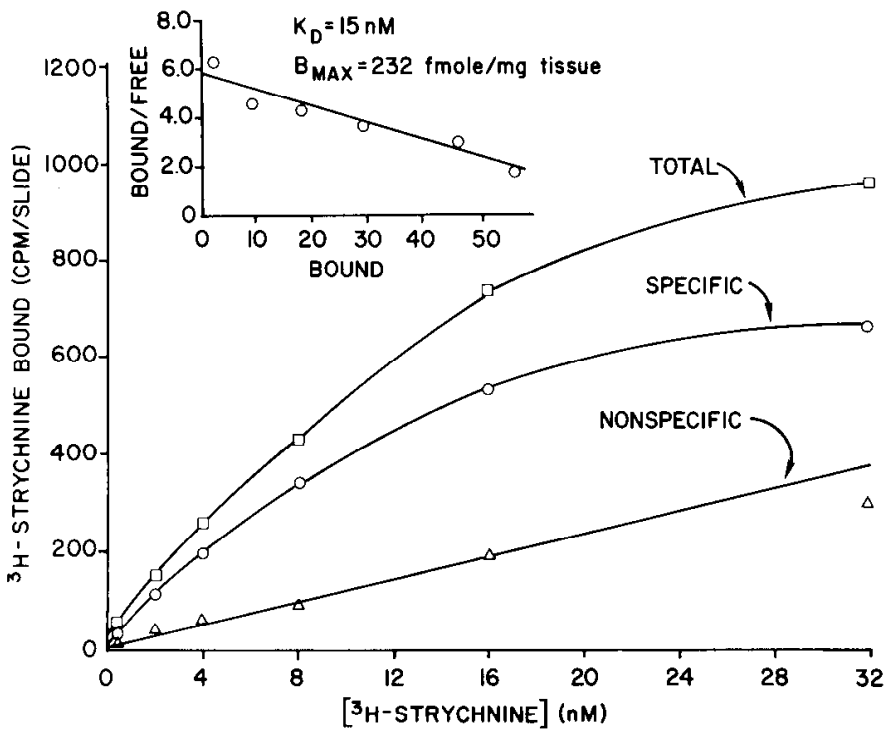

Figure 3. Saturation kinetics (at $4^{\circ} \mathrm{C}$ ) of $\left[{ }^{3} \mathrm{H}\right]$ strychnine binding to slide-mounted tissue sections. Specific binding $(O)$ is obtained by subtracting nonspecific binding $(\Delta)$, defined as binding in the presence of $10 \mathrm{~mm}$ glycine, from total binding ( $\square$ ). The dissociation time for all observations was $5 \mathrm{~min}$, and the association time was $20 \mathrm{~min}$. Each point is an average of two determinations which differed by less than $10 \%$. Inset shows a Scatchard plot of the saturation data. $K_{D}=15 \mathrm{~mm} ; B_{\max }=$ $232 \mathrm{fmol} / \mathrm{mg}$ of tissue.

had nearly no autoradiographic grains. In lumbar regions, grain densities were more similar in the various laminae. The high density observed over laminae II and III was the same whether lumbar, thoracic, or cervical regions of the spinal cord were examined. In the lumbar and cervical limb enlargements, however, the grain density over laminae V, VII (dorsal), and IX increased significantly. In general, the neuropil contained the highest density of grains, while relatively few grains were observed directly over the large and small cells of the spinal cord. Exceptions to this generalization were noted in laminae II and III in which some grains were observed over the small cells and in lamina IX where some grains were over the small cells and large cells.

Medulla. The autoradiographic grains in the medulla (Fig. 6) were highly localized in contrast to those observed in the spinal cord. The highest density of grains was observed over the hypoglossal nucleus (nXII) and the nucleus intercalatus (nic). High grain densities also were noted over the medullary trigeminal nuclei, i.e., substantia gelatinosa trigemini $(\mathrm{sgV})$, nucleus tractus spinalis nervi trigemini pars dorsomedialis (ntVd), and nucleus tractus spinalis nervi trigemini (ntV). The dorsal motor nucleus of the vagus nerve (DMN of $\mathrm{X}$ ), the cuneate (cu) and gracile (gr) nuclei, nucleus reticularis lateralis (rl), and nucleus reticularis medullae oblongatae pars ventralis (nrv) had high densities as well. Lower grain densities were noted over the components of the medullary reticular formation (note that nrv is an exception), including nucleus reticularis medullae oblongatae pars dorsalis (nrd), nucleus reticularis paramedianus (nrp), nucleus reticularis gigantocellularis (rgi), the rostral part of nucleus reticularis parvocellularis (rpc), and the nucleus olivaris inferior (io). The caudal part of rpc had the lowest grain density in the medullary reticular formation. The nucleus ambiguus (amb) and the nucleus raphe magnus (rm) were associated with grain densities comparable to those over the components of the reticular formation. Of the medullary nuclei which were identified, only the nucleus tractus solitarii was observed to be associated with a negligible grain density. As noted in the spinal gray matter, the neuropil clearly was associated with the bulk of the autoradiographic grains, while large and small cells had few or no grains visible over them. Exceptions to this generalization were noted, however. In nXII, rm, rgi, amb, and io, grains could be seen over the large cells. This observation was made also in DMN of X and nrp but was less frequent. Finally, the small cells of io and $\mathrm{rm}$ were associated with grains.

Pons. As in the medulla, the distribution of autoradiographic grains in the pons (Fig. 7) was highly localized. The highest density of grains was observed over the facial nucleus (nVII) and the trigeminal nuclei including nucleus originis nervi trigemini $(\mathrm{nV})$, nucleus principalis nervi trigemini $(\mathrm{npV})$, and $\mathrm{ntVd}$. Lower grain densities were observed over nuclei containing secondary and tertiary neurons of the acoustic system: nucleus cochlearis dorsalis (cod), nuclei lemnisci lateralis partes rostralis (M. A. Zarbin, J. K. Wamsley, and M. J. Kuhar, unpublished observation), ventralis, and dorsalis (llr, llv, lld), and nucleus olivaris superior (os). Similar grain densities were noted over nucleus vestibularis medialis (vm), substantia grisea centralis ventralis (SGCv), nucleus suprageniculatis facialis (sg), and nuclei parabrachialis ventralis (npv) and dorsalis (npd). Lower grain densities were observed over the substantia grisea centralis dorsalis (SGCd), nucleus raphis dorsalis (rd), the inferior colliculus (Ci), nucleus preolivaris externus (ope), and nucleus vestibularis superior (vs). A significant density of autoradiographic grains, quantitatively comparable to that noted over the medullary reticular formation, was associated with the pontine reticular formation. Specifically, higher grain densities were noted over the rostral parts of nucleus reticularis pontis oralis (rpoo) and nu-

\section{TABLE I}

Competition for specific $\left[{ }^{3} \mathrm{H}\right]$ strychnine binding

Slide-mounted tissue sections were incubated with $4 \mathrm{nM}\left[{ }^{3} \mathrm{H}\right]$ strychnine and $10^{-4} \mathrm{M}$ concentration of a given compound. Incubations were carried out at $4^{\circ} \mathrm{C}$ for $20 \mathrm{~min}$.

\begin{tabular}{lcc}
\hline \multicolumn{1}{c}{ Compound } & Concentration & $\begin{array}{c}\text { \% Displace- } \\
\text { ment }^{\text {a }}\end{array}$ \\
\hline Glycine & $M$ & \\
$\alpha$-Alanine & $10^{-4}$ & 69 \\
$\beta$-Alanine & $10^{-4}$ & 15 \\
Taurine & $10^{-4}$ & 63 \\
L-Serine & $10^{-4}$ & 25 \\
L-Proline & $10^{-4}$ & 17 \\
GABA & $10^{-4}$ & 10 \\
$\delta$-Aminovaleric acid & $10^{-4}$ & 4 \\
Atropine & $10^{-4}$ & 1 \\
Triprolidine & $10^{-4}$ & 4 \\
\hline
\end{tabular}

${ }^{a}$ Displacement of specific $\left[{ }^{3} \mathrm{H}\right]$ strychnine binding. Each value is the average of four determinations which differed by less than $10 \%$. See text for details. 
TABLE II $^{3}$

Distribution of $\left[{ }^{3} \mathrm{H}\right]$ strychnine receptors in rat $\mathrm{CNS}$

Data refer to specific density of autoradiographic grains per $529 \mu \mathrm{m}^{2}$ as visualized over a given locus and are reported as mean \pm SEM. Specific density is defined as the density in the absence of $10^{-2} \mathrm{M}$ glycine minus the density in the presence of $10^{-2} \mathrm{M}$ glycine (which was usually between 5 and 8 grains $/ 529 \mu \mathrm{m}^{2}$ ). Each observation is an average of five measurements. The experiment was repeated in three animals with no qualitatively or quantitatively significant variation in the tissue. See text for details.

\begin{tabular}{|c|c|c|c|}
\hline Region & $\begin{array}{l}\text { Specific Density } \\
\text { of Grains } / 529 \mu \mathrm{m}^{2}\end{array}$ & Region & $\begin{array}{l}\text { Specific Density } \\
\text { of Grains } / 529 \mu \mathrm{m}^{2}\end{array}$ \\
\hline \multicolumn{2}{|l|}{ Thoracic spinal cord } & \multicolumn{2}{|l|}{ Medulla } \\
\hline Lamina I & $16 \pm 4$ & nXII and nic & $123 \pm 11$ \\
\hline Laminae II, III & $122 \pm 14$ & DMN of $\mathrm{X}$ & $86 \pm 10$ \\
\hline Lamina IV & $52 \pm 6$ & $\mathrm{amb}$ & $41 \pm 4$ \\
\hline Lamina V (medial) & $36 \pm 13$ & $\mathrm{ntV}$ & $84 \pm 7$ \\
\hline Lamina V (lateral) & $90 \pm 11$ & sgV & $110 \pm 12$ \\
\hline Lamina VII (ventromedial) & $77 \pm 12$ & ntVd & $77 \pm 8$ \\
\hline Lamina VII (dorsal) & $136 \pm 17$ & cu & $69 \pm 11$ \\
\hline Lamina VIII & $68 \pm 10$ & $\mathrm{gr}$ & $69 \pm 11$ \\
\hline Lamina IX & $42 \pm 9$ & $\mathrm{rl}$ & $87 \pm 8$ \\
\hline Lamina $\mathrm{X}$ & $62 \pm 10$ & nrd & $29 \pm 5$ \\
\hline \multirow[t]{2}{*}{ Lateral funiculus } & $0 \pm 1$ & nrv & $79 \pm 11$ \\
\hline & & nrp & $26 \pm 8$ \\
\hline \multicolumn{2}{|c|}{ Cervical spinal cord (limb enlargement) } & rgi & $52 \pm 6$ \\
\hline Lamina I & $18 \pm 2$ & rpc (rostal) & $42 \pm 7$ \\
\hline Laminae II, III & $129 \pm 17$ & rpc (caudal) & $12 \pm 3$ \\
\hline Lamina IV & $72 \pm 11$ & rm & $33 \pm 6$ \\
\hline Lamina V (medial) & $71 \pm 4$ & io & $45 \pm 8$ \\
\hline Lamina V (lateral) & $127 \pm 16$ & nts & $1 \pm 1$ \\
\hline Lamina VII (ventromedial) & $88 \pm 8$ & $\mathrm{PCI}$ & $0 \pm 1$ \\
\hline Lamina VII (dorsal) & $197 \pm 23$ & & \\
\hline Lamina VIII & $81 \pm 7$ & Pons & \\
\hline Lamina IX (lateral group) & $94 \pm 8$ & nVII & $98 \pm 12$ \\
\hline Lamina $\mathrm{X}$ & $89 \pm 8$ & $\mathrm{nV}$ & $85 \pm 11$ \\
\hline \multirow[t]{2}{*}{ Lateral funiculus } & $0 \pm 1$ & $\mathrm{npV}$ & $93 \pm 7$ \\
\hline & & ntVd & $77 \pm 8$ \\
\hline \multicolumn{2}{|l|}{ Cerebellum } & vm & $55 \pm 3$ \\
\hline Nucleus dentatus & $0 \pm 1$ & $\mathrm{vl}$ & $9 \pm 2$ \\
\hline Fastigial nucleus & $0 \pm 1$ & vs & $24 \pm 4$ \\
\hline Nucleus interpositus & $4 \pm 1$ & os & $58 \pm 5$ \\
\hline Cortex: & & osa, osp & $7 \pm 2$ \\
\hline Molecular layer & $0 \pm 1$ & ope & $13 \pm 1$ \\
\hline Granule layer & $0 \pm 1$ & ct & $1 \pm 1$ \\
\hline \multirow[t]{2}{*}{ Purkinje layer } & $0 \pm 1$ & $\operatorname{cod}$ & $43 \pm 6$ \\
\hline & & $\operatorname{cov}$ & $0 \pm 1$ \\
\hline \multicolumn{2}{|l|}{ Midbrain } & lld & $74 \pm 9$ \\
\hline nIII & $12 \pm 2$ & llv & $63 \pm 7$ \\
\hline ncu and $A 8$ & $21 \pm 3$ & PCS & $3 \pm 1$ \\
\hline ncu (rostal) & $72 \pm 9$ & PCM & $0 \pm 1$ \\
\hline snr & $21 \pm 12$ & $\mathrm{TM}$ & $0 \pm 1$ \\
\hline ip & $13 \pm 3$ & $\mathbf{P}$ & $0 \pm 1$ \\
\hline sgs & $27 \pm 8$ & SGCv & $33 \pm 9$ \\
\hline sgm & $29 \pm 4$ & SGCd & $10 \pm 3$ \\
\hline sgp & $31 \pm 18$ & nIV & $3 \pm 7$ \\
\hline $\mathbf{r}$ & $15 \pm 9$ & nVI & $4 \pm 5$ \\
\hline SGCv & $27 \pm 6$ & sg & $38 \pm 4$ \\
\hline SGCd & $31 \pm 6$ & rd & $24 \pm 6$ \\
\hline EW & $14 \pm 6$ & npv & $44 \pm 6$ \\
\hline $\mathrm{iC}$ and $\mathrm{nD}$ & $6 \pm 2$ & npd & $36 \pm 5$ \\
\hline \multirow[t]{2}{*}{ FLM } & $3 \pm 2$ & po & $3 \pm 1$ \\
\hline & & rpoc (rostal) & $33 \pm 4$ \\
\hline \multicolumn{2}{|l|}{ Thalamus } & rpoc (caudal) & $20 \pm 4$ \\
\hline pf & $43 \pm 8$ & $\mathrm{rtp}$ & $51 \pm 9$ \\
\hline ZI & $25 \pm 5$ & rpoo (rostral) & $51 \pm 8$ \\
\hline $\mathrm{dcgl}$ & $0 \pm 10$ & rpoo (caudal) & $5 \pm 3$ \\
\hline vcgl & $15 \pm 7$ & lc & $0 \pm 1$ \\
\hline tv and tvd & $4 \pm 2$ & ntm & $3 \pm 1$ \\
\hline \multirow[t]{2}{*}{ tpm } & $11 \pm 7$ & $\mathrm{Ci}$ & $12 \pm 1$ \\
\hline & & ntd, ntdl & $4 \pm 1$ \\
\hline \multicolumn{2}{|l|}{ Cerebral cortex } & & \\
\hline All layers & $0 \pm 1$ & & \\
\hline
\end{tabular}


cleus reticularis pontis caudalis (rpoc), and nucleus reticularis tegmenti pontis (rtp). Lower grain densities were noted over the caudal parts of rpoc and rpoo. The density of grains over the pontine nuclei (po) was not significantly different from emulsion background.

Outside of the reticular formation, the pons, in contrast to the medulla, contained several nuclear groups which were associated with very low grain densities. Very low grain densities were noted over the abducens (nVI) and trochlear (nIV) nuclei, for example. Similarly, low densities were noted over the locus coeruleus (lc), nucleus tractus mesencephali (ntm), nucleus tegmenti dorsalis (ntd) and nucleus tegmenti dorsalis lateralis (ntdl), nucleus vestibularis lateralis (vl), nucleus corporis trapezoidei (ct), nucleus cochlearis ventralis (cov), nucleus accessorius olivaris superioris (osa) and nucleus parolivaris superioris (osp), and over white matter tracts, such as the tractus corticospinalis $(\mathrm{P})$, pedunculi cerebellaris inferior (PCI), medius (PCM) and superior (PCS), and the tractus mesencephalicus nervi trigemini (TM). Again, the neuropil contained most of the autoradiographic grains, while relatively few grains were visualized over the large and small cells. Some exceptions to this generalization are as follows. The facial nucleus (nVII), $\mathrm{nV}$, os, sg, cod, and rtp contained large cells over which some grains could be visualized. This was noted also in the cases of SGCd, SGCv, vl, nIV, and Ci but not as frequently. Grains were visualized over some of the small cells in vl, rd, cod, $\mathrm{Ci}$, and rtp.

Mesencephalon. In the midbrain, the density of $\left[{ }^{3} \mathrm{H}\right] \mathrm{SBS}$ was, in general, much lower than in the pons and medulla, although several areas were found to contain significant densities of $\left[{ }^{3} \mathrm{H}\right] \mathrm{SBS}$ (Table II). The rostral part of the cuneiform nucleus ( $\mathrm{ncu}$ ) was associated with the highest density of $\left[{ }^{3} \mathrm{H}\right] \mathrm{SBS}$ in the midbrain. Lower, but significant, grain densities were noted over the caudal part of the ncu and the adjacent area $A 8$, the pars reticulata of the substantia nigra (snr), the dorsal and ventral parts of the substantia grisea centralis (SGCd and SGCv), and the cellular layers of the superior colliculus, i.e., stratum griseum superficiale (sgs), stratum gri- seum mediale (sgm), and stratum griseum profundun (sgp) colliculi superioris (Table II). Still lower densities were noted over the interpeduncular nucleus (ip), the red nucleus ( $\mathrm{r}$ ), nucleus oculomotoris (nIII), and the EdingerWestphal nucleus (FW). The interstitial nucleus of Cajal (iC) and the medial longitudinal fasciculus (FLM) were associated with a $\left[{ }^{3} \mathrm{H}\right] \mathrm{SBS}$ density not significantly different from background (Table II). As before, the grains tended to be concentrated in the neuropil and were seen over cell bodies less frequently. It was noted that the distribution of grains in ip was very similar to that described for $\left[{ }^{3} \mathrm{H}\right]$ propylbenzylcholine mustard by Rotter et al. (1979).

Diencephalon. In the thalamus (Fig. 8), there was a rather high density of $\left[{ }^{3} \mathrm{H}\right] \mathrm{SBS}$ in the parafascicular nucleus (pf). The zona incerta (ZI), the paramedian thalamic nucleus (tpm), and the ventral lateral geniculate body (vcgl) also had significant densities of $\left[{ }^{3} \mathrm{H}\right] \mathrm{SBS}$. Lower grain densities were observed over the ventral thalamic nuclei (tv and tvd).

An extremely low density of $\left[{ }^{3} \mathrm{H}\right] \mathrm{SBS}$ was visualized over all components of the cerebellum (Fig. 7 and Table II). Similarly, all areas of the cerebral cortex (Fig. 8) were associated with grain densities not significantly greater than background.

\section{Discussion}

In this study, an in vitro labeling autoradiographic method (Young and Kuhar, 1979a) was used to map the distribution of GRs in the rat CNS. This quantitative and highly reproducible procedure has been employed previously to localize the receptors for other drugs and neurotransmitters (Palacios et al., 1980; Wamsley et al., 1980a; Young and Kuhar, 1979a; Young and Kuhar, 1980). Autoradiograms were generated using slidemounted tissue sections which were labeled with $\left[{ }^{3} \mathrm{H}\right]$ strychnine. The binding of $\left[{ }^{3} \mathrm{H}\right]$ strychnine to these tissue sections had the pharmacologic and kinetic characteristics associated with the synaptic GR (Young and Snyder, 1973, 1974a, b; Muller and Snyder, 1978) studied previously in homogenates.

\footnotetext{
${ }^{3}$ The abbreviations used are: amb, nucleus ambiguus; $\mathrm{Ci}$, colliculus inferior; cod, nucleus cochlearis dorsalis; cov, nucleus cochlearis ventralis; ct, nucleus corporis trapezoidei; cu, nucleus cuneatus; dcgl, nucleus dorsalis corporis geniculati lateralis; DMN of $\mathrm{X}$, nucleus originis dorsalis vagi; EW, nucleus Edinger-Westphal; FLM, fasciculus longitudinalis medialis; gr, nucleus gracilis; iC, nucleus interstitialis Cajal; io, nucleus olivaris inferior; ip, nucleus interpeduncularis; lc, locus coeruleus; lld, nucleus lemnisci lateralis dorsalis; llr, nucleus lemnisci lateralis rostralis; llv, nucleus lemnisci lateralis ventralis; LM, lemniscus medialis; $N$, nodulus; ncu, nucleus cuneiformis; $\mathrm{nD}$, nucleus accessorius Darkschewitsch; nic, nucleus intercalatus; nIII, nucleus originis nervi oculomotorii; nIV, nucleus originis nervi trochlearis; npd, nucleus parabrachialis dorsalis; npv, nucleus parabrachialis ventralis; $n p V$, nucleus principalis nervi trigemini; nrd, nucleus reticularis medullae oblongatae pars dorsalis; nrp, nucleus reticularis paramedianus; nrv, nucleus reticularis medullac oblongatac pars ventralis; ntd, nucleus tegmenti dorsalis Gudden; ntdl, nucleus tegmenti dorsalis lateralis; ntm, nucleus tractus mesencephali; $n t s$, nucleus tractus solitarii; $n t V$, nucleus tractus spinalis nervi trigemini; ntVd, nucleus tractus spinalis nervi trigemini pars dorsomedialis; $\mathbf{n V}$, nucleus originis nervi trigemini; $\mathbf{n V I}$, nucleus originis nervi abducentis; nVII, nucleus originis nervi facialis; nXII, nucleus
}

originis nervi hypoglossi; ope, nucleus preolivaris externus; os, nucleus olivaris superior; osa, nucleus accessorius olivaris superioris; osp, nucleus parolivaris superioris; $\mathrm{P}$, tractus corticospinalis; $\mathrm{PCI}$, pedunculus cerebellaris inferior; PCM, pedunculus cerebellaris medius; PCS, pedunculus cerebellaris superior; pf, nucleus parafascicularis; po, nuclei pontis; r, nucleus ruber; rd, nucleus raphis dorsalis; rgi, nucleus reticularis gigantocellularis; $r l$, nucleus reticularis lateralis; $r m$, nucleus raphe magnus; rpc, nucleus reticularis parvocellularis; rpoc, nucleus reticularis pontis caudalis; rpoo, nucleus reticularis pontis oralis; rtp, nucleus reticularis tegmenti pontis; sg, nucleus suprageniculatus facialis; SGCd, substantia grisea centralis dorsalis; SGCv, substantia grisea centralis ventralis; sgm, stratum griseum mediale colliculi superioris; sgp, stratum griseum profundum colliculi superioris; sgs, stratum griseum superficiale colliculi superioris; sgV, substantia gelatinosa trigemini; snr, substantia nigra zona reticularis; TM, tractus mesencephalicus nervi trigemini; tpm, nucleus posteromedianus thalami; $t v$, nucleus ventralis thalami; tvd, nucleus ventralis thalami, pars dorsomedialis; vcgl, nucleus ventralis corporis geniculati lateralis; vl, nucleus vestibularis lateralis; vm, nucleus vestibularis medialis; vs, nucleus vestibularis superior; ZI, zona incerta. The terminology and abbreviations are those of Konig and Klippel (1963). 

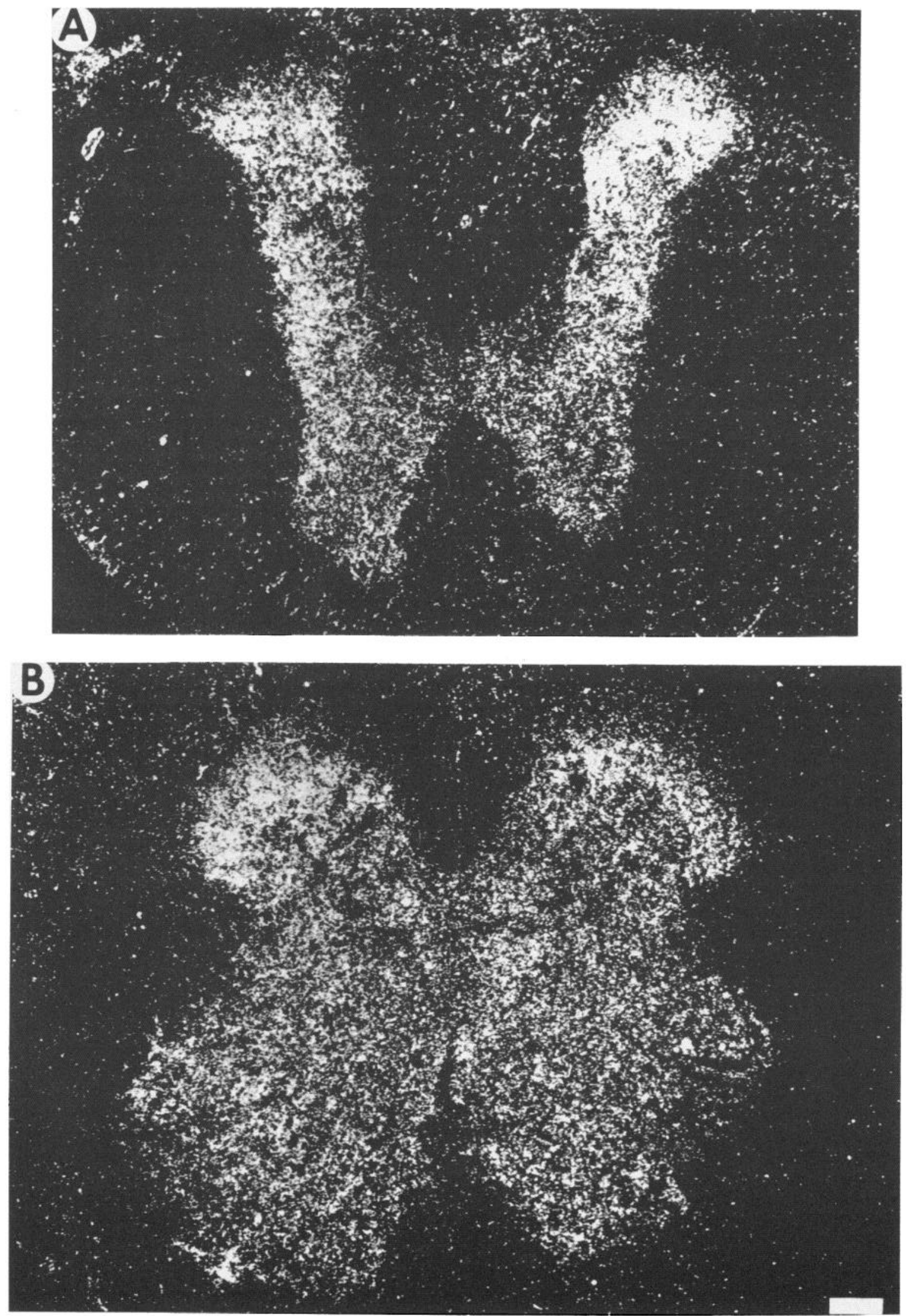

Figure 4. Dark-field photomicrographs demonstrating autoradiographic grains seen over the thoracic $(A)$ and lumbar $(B)$ regions of the rat spinal cord. Tissue sections were labeled with $\left[{ }^{3} \mathrm{H}\right]$ strychnine; note the high density of glycine receptors in lamina II (substantia gelatinosa) and the diffuse distribution of glycine receptors throughout the rest of the gray matter of the cord with negligible grain densities over the funiculi. In this, as in all following photomicrographs, the photo gives only a qualitative indication of the actual grain density. Bar $=100 \mu \mathrm{m}$. See text for details. 

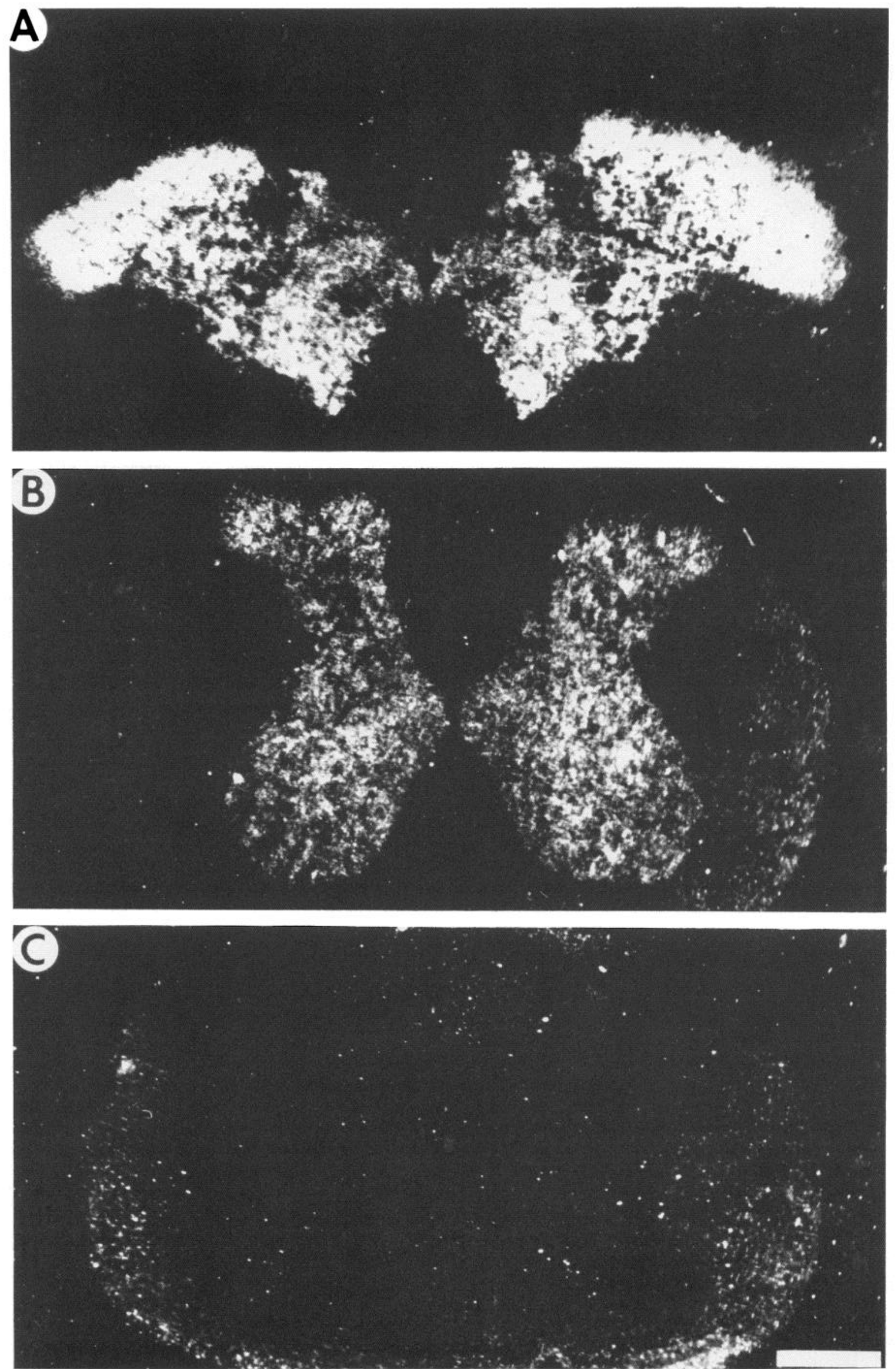

Figure 5. Dark-field photomicrographs demonstrating autoradiographic grains seen over the upper cervical level $(A)$ and cervical limb enlargement $(B)$ of the rat spinal cord. $C$ is a control section incubated in the presence of $10^{-2} \mathrm{M}$ glycine. The negligible density of grains over $C$ suggests that nonspecific strychnine binding was very low. Bar $=1 \mathrm{~mm}$. See text for details. 

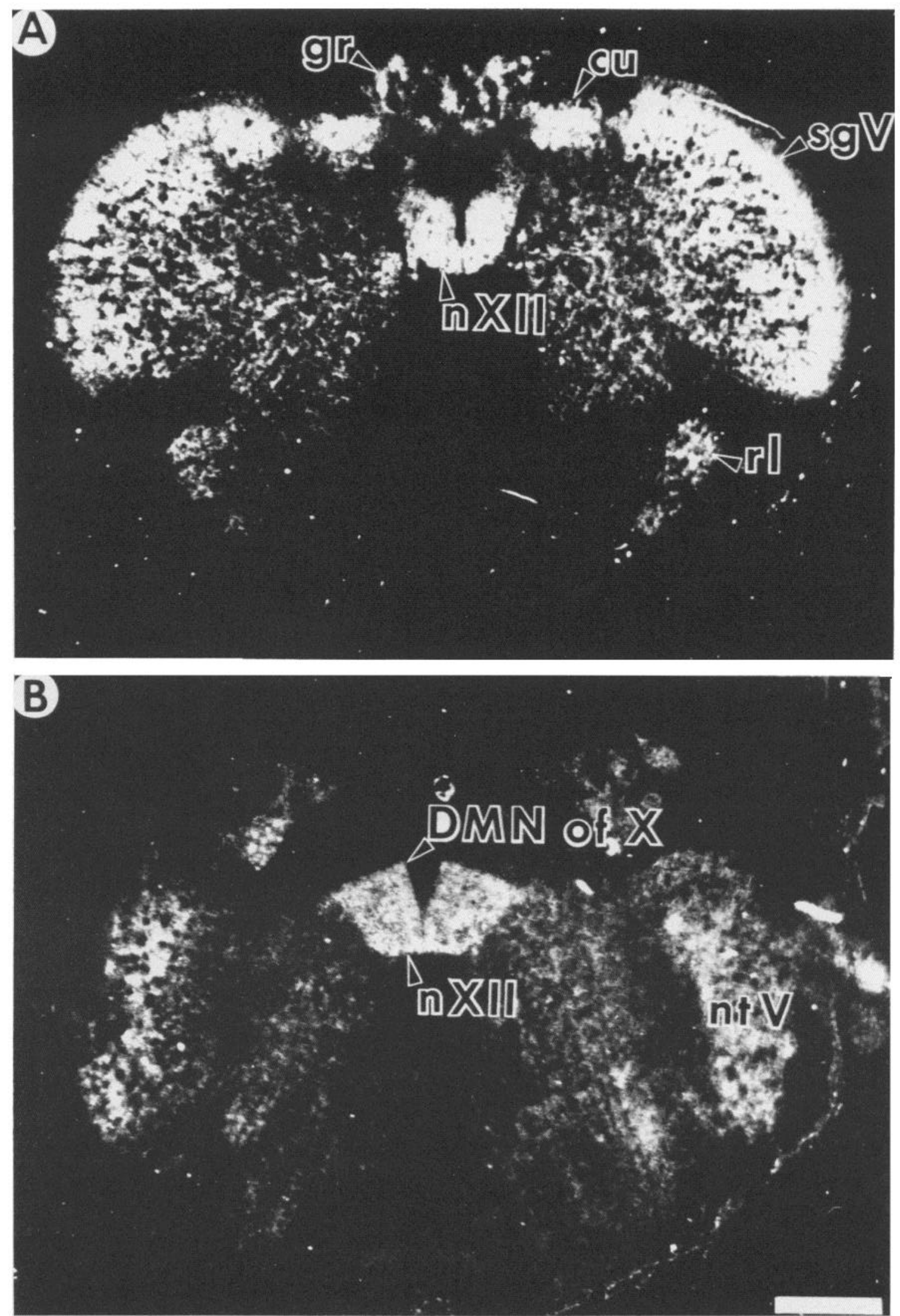

Figure 6. Dark-field photomicrographs of glycine receptors in the lower $(A)$ and upper $(B)$ levels of the rat medulla oblongata. Note the high density of autoradiographic grains seen over the hypoglossal (nXII) nucleus, the dorsal motor nucleus of the vagus $(\mathrm{DMN}$ of $\mathrm{X})$, and the substantia gelatinosa trigemini $(\mathrm{sgV})$. Bar $=1 \mathrm{~mm}$. Abbreviations are listed in Footnote 3 . See text for details. 

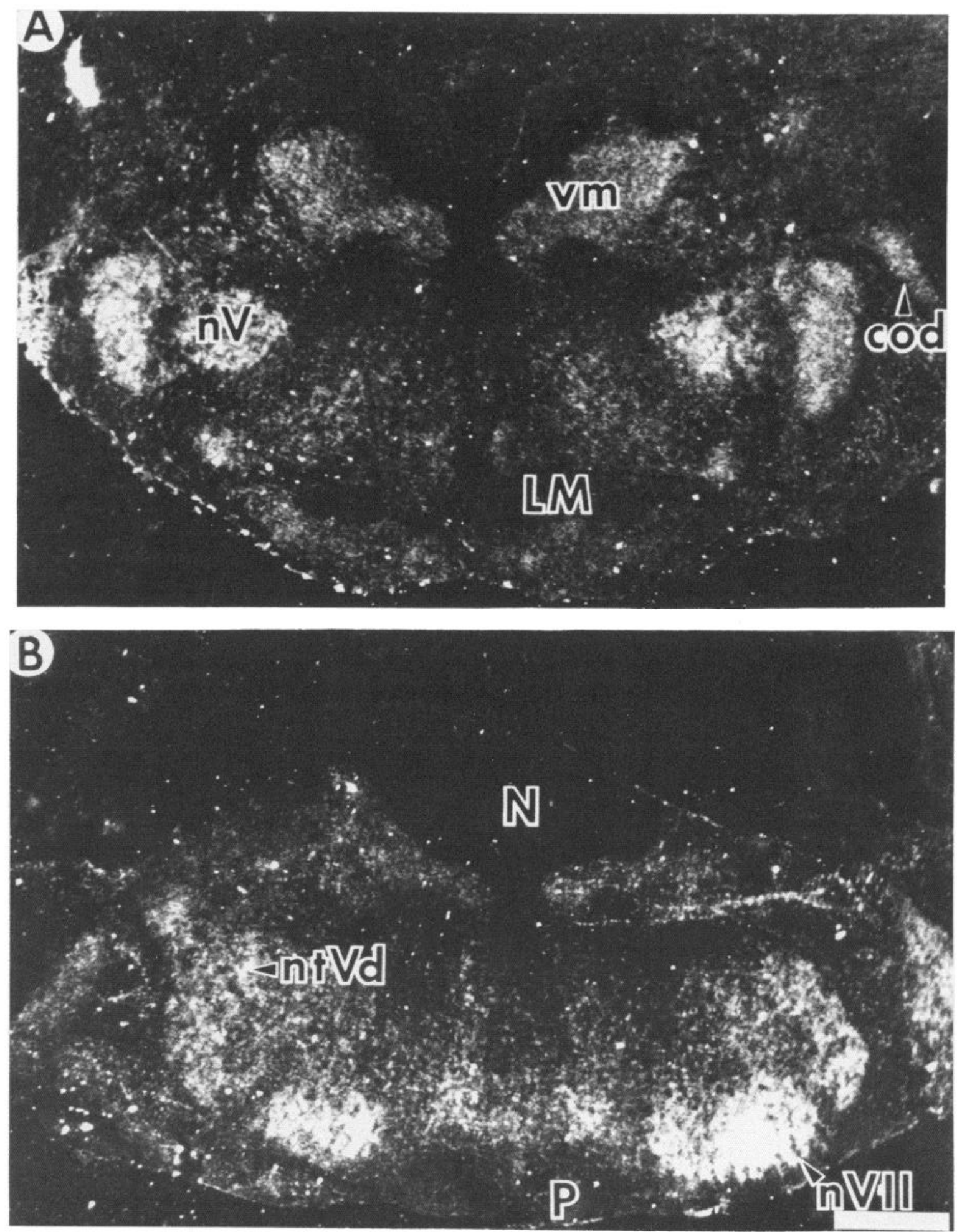

Figure 7. Dark-field photomicrographs of glycine receptors in upper $(A)$ and lower $(B)$ levels of the rat pons. Note the high density of grains over the facial nucleus (nVII), the nucleus originis of the trigeminal nerve (nV), and the nucleus of the spinal tract of the trigeminal nerve, pars dorsomedialis (ntVd). Note also the negligible density of grains over the nodulus $(\mathrm{N})$ and other cerebellar areas. Bar $=1 \mathrm{~mm}$. Abbreviations are listed in Footnote 3. See text for details.

The gross regional distribution of GRs is in excellent accord with that observed in homogenate preparations (Young and Snyder, 1973). The density of receptors is highest in the gray matter of the spinal cord, decreases progressively as one ascends the neuraxis, and is apparently negligible in the cerebellum and cerebrum. This study has extended the description of that gradient to the level of resolution of light microscopy. 


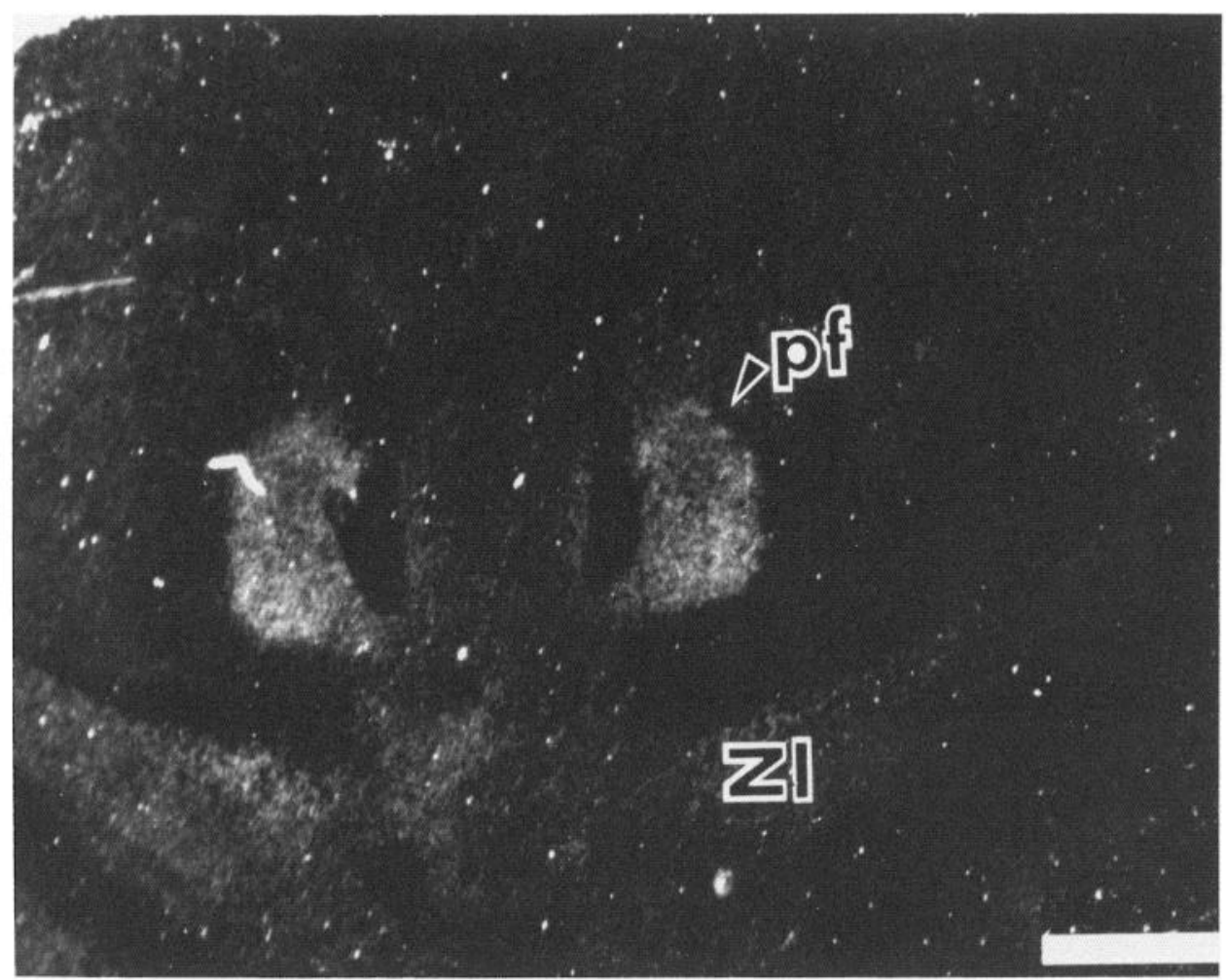

Figure 8. Dark-field photomicrograph of glycine receptors in the rat thalamus (A3290u, Konig and Klippel, 1963). Note the high density of glycine receptor in the zona incerta (ZI). Note also the negligible density of receptors in surrounding cortical and amygdaloid areas. Bar $=1 \mathrm{~mm}$. See text for details.

\section{Correlation with electrophysiologic data}

Within a given anatomic region, there is an extraordinarily good correspondence between loci of high SBS density and loci in which strychnine has been shown to be electrophysiologically active. These regions include the spinal cord (Lodge et al., 1977; Curtis et al., 1976; Belcher et al., 1976; Game and Lodge, 1975), the medulla and pons (Felpel, 1977; Altmann et al., 1972; Yokota et al., 1979; Caspary et al., 1979; Kelly and Renand, 1973; Headley and Lodge, 1976; Kiczka et al., 1977; Morimoto et al., 1968; Tebecis and DiMaria, 1972; Kidokoro et al., 1968; Felpel, 1972; Haas and Hosli, 1973; Feldberg and Guertzenstein, 1976), and the midbrain and thalamus (Ishida, 1977; Ascher and Gachelin, 1967; Glowinski, 1979; Apter, 1946).

Electrophysiological data regarding the action of strychnine on the cerebral cortex are difficult to interpret. Kelly and Krnjevic $(1968,1969)$ have shown that glycine is only $25 \%$ as potent as GABA when iontophoresed onto the cat cerebral cortex. Their results suggest that the density of synaptic glycine receptors is relatively low in the cerebrum. This finding corroborates the nearly negligible density of $\left[{ }^{3} \mathrm{H}\right] \mathrm{SBS}$ which was observed throughout the cerebral cortex (Table II). Others have found (Crighel, 1966; Rayport and Jasper, 1958; Creutzfeldt et al., 1956), however, that strychnine has electrophysiologically measurable effects on cells in the cerebral cortex. Since these studies have utilized very high concentrations of strychnine (in the range of $10^{-4}$ to $10^{-3} \mathrm{M}$ ), the effects could be due to any of the many so-called nonspecific effects of strychnine, such as its curare-like action (Bhargava and Meldrum, 1969), its direct effect on axonal membranes (Freeman, 1973; Wall and Horowitz, 1951), its anticholinesterase activity (Alid et al., 1974), or, perhaps, other unknown extrasynaptic effects. Many other areas in which very low or nondetectable densities of $\left[{ }^{3} \mathrm{H}\right] \mathrm{SBS}$ were observed are electrophysiologically unresponsive to strychnine (Altmann et al., 1973, 1976; Kier et al., 1966; Brooks and Asanuma, 1965; Crawford et al., 1963; Krnjevic et al., 1966; Kawamura and Provini, 1970; Galindo, 1969; Ito, 1976).

Some investigators (Gogolak et al., 1974) have noted that strychnine potently influences the cerebellorubral circuit. This finding does not corroborate the very low grain densities that were noted over the red nucleus and the cerebellum (Table II). In these experiments, however, strychnine was administered systemically. Thus, strychnine may have had its effect, in part, by acting through reticulocerebellar circuits, e.g., those involving the lateral reticular nucleus, the paramedian reticular nucleus, or the tegmental pontine reticular nucleus, areas of high SBS density. Similarly, although the data presented in this study suggest that the density of SBS is very low over the nucleus of the solitary tract, Kiczka et al. (1977) have found that strychnine, administered systemically in subconvulsive doses, can block vagally induced inhibition of the activity of laryngeal motoneurons in the cat. One explanation for their results is that strychnine exerts its effect by acting directly on cells in the nucleus ambiguus, an area of significant receptor density.

While Caspary et al. (1979) have found that cells in 
the ventral cochlear nucleus (cov) are sensitive to iontophoretic application of strychnine (although cells in the dorsal cochlear nucleus were more sensitive), the data presented in Table II suggest that strychnine should be electrophysiologically ineffective in cov. Their experiments were carried out in chincillas, however, and thus, species differences may account for this and other discrepancies. We have noted striking species differences for the distribution of other receptors, such as benzodiazepines (Young and Kuhar, 1979b), opioids (J. K. Wamsley, M. A. Zarbin, W. S. Young, III, and M. J. Kuhar, submitted for publication), and histamine (Palacios et al., 1981).

\section{Correlation between glycinergic terminal density and GR density}

On a gross scale, it has been shown that endogenous glycine levels (Aprison et al., 1969; Aprison and Nadi, 1977), high affinity synaptosomal glycine uptake (Logan and Snyder, 1972), and unique glycine-accumulating synaptosomes (Arregui et al., 1972) are most concentrated in the spinal cord and brainstem. As indicated above, this is precisely the gross distribution of GRs which was observed autoradiographically.

Matus and Dennison (1971) and others (Price et al., 1976) mapped the distribution of putative glycinergic nerve terminals in the ventral horn of the rat by localizing glycine uptake sites. They noted the presence of uptake sites in the neuropil and around the cell bodies. This description is very similar to the distribution of GRs which was observed in the ventral horn. Ribeiro-da-silva and Coimbra (1980) have demonstrated the existence of neuronal high affinity glycine uptake sites in laminae I, II, and III of the rat spinal cord. The grains were found throughout the neuropil of these laminae and over certain somata in lamina III. This distribution is very similar to that observed for GRs in these laminae. Aprison and Nadi (1977) have shown that the ratio of dorsal horn glycine content to ventral horn glycine content is approximately 0.8 , i.e., only slightly less dorsally than ventrally. Assuming that the fraction of glycine associated with synaptic activity and the content of synaptically active glycine per nerve terminal is approximately the same in the dorsal and ventral horns, one anticipates that the ratio of $\left[{ }^{3} \mathrm{H}\right]$ strychnine receptors in the dorsal horn to that in the ventral horn will be about 0.8 (if glycinergic nerve terminal density is related to SBS density). From the data in Table II, the ratio of receptor densities is calculated to be 0.78 .

Aprison et al. (1969) have shown that spinal cord glycine content is highest in regions of the limb enlargements. The autoradiographic data presented in Table II show that the density of GRs is higher (on the average) in the ventral gray matter of the cervical limb enlargement than in the thoracic region of the cord $(p<0.005$, Student's paired $t$ test). On the other hand, the dorsal gray matter in these two areas contains equivalent densities of GRs ( $p<0.1$, Student's paired $t$ test). This suggests that the regional variation in glycine content may be due, primarily, to variations in ventral horn glycine levels. Within the ventral horn of the spinal cord, there are also local variations in receptor density changes. In other words, when comparing cervical to thoracic regions, the density of SBS is not increased uniformly in the ventral horn. The increase in the mean ventral horn SBS density appears to be largely attributable to (1) an increased density of SBS in laminae which receive terminals of fiber tracts influencing the limb (as opposed to the trunk) musculature (e.g., the lateral part of lamina $\mathrm{V}$ and the dorsal part of lamina VII) and (2) an increased density of SBS in lamina IX.

Wamsley et al. (J. K. Wamsley, J. M. Palacios, and M. J. Kuhar, submitted for publication) have demonstrated the existence of GRs in the inner plexiform layer of the retina. This area is known to contain high affinity glycine uptake and to release glycine upon visual stimulation (Ehinger and Lindberg, 1974).

Roberts (1974) has shown that in vivo stimulation of the cat medial lemniscus causes a significant increase in the release of glycine (and GABA) in the cuneate nucleus, and strychnine has been shown to antagonize the effect of glycine in this nucleus specifically (Hill et al., 1976; Kelly and Renand, 1973). These findings, taken with the data of Table II, correlate the presence of GRs in the cuneate nucleus with the presence of nerve terminals which, when stimulated, release glycine.

Finally, Battistin et al. (1969) have shown neurochemically that the thalamus contains a relatively high content of glycine. The data presented here suggest that, if thalamic glycine has a role in neurotransmission, then it should be found in the intralaminar nuclei.

The data presented in Table II suggest other loci (particularly nXII, nVII, rl, laminae II and III of the spinal cord, llv, lld, and DMN of X) in which the existence of high glycine levels, high affinity synaptosomal glycine uptake, or synaptic terminals containing glycine-labile pleomorphic vesicles may be sought.

\section{Physiologic functions associated with GRs}

As described above, GRs are highly localized to specific nuclei. This localization indicates that GRs are associated with particular physiologic systems and functions.

Afferent systems. Afferent systems will be considered first. Examination of Table II reveals that 30 to $40 \%$ of the GRs in the dorsal horn are found in laminae II and III. This very high receptor density is apparently constant throughout the spinal cord and is not statistically different from the reported density in the substantia gelatinosa of the trigeminal subnucleus caudalis which is a rostral extension of laminae II. In addition, 40 to $50 \%$ of the dorsal horn's GRs are located in lamina V. Since neurons in laminae I, II, and V are known to respond maximally to nociceptive stimuli (Basbaum and Fields, 1978), these data suggest that glycinergic neurons may have role in the modulation of nociception. There is evidence which supports this hypothesis. Yokota et al. (1979) have shown that strychnine, when administered to monkeys intravenously, causes an expansion of the receptive field and lowering of the response threshold of neurons ventromedial to the trigeminal subnucleus caudalis pars magnocellularis. These neurons are analogous to lamina $\mathrm{V}$ neurons of the spinal cord (Yokota et al., 1979 and Hillman and Wall, 1969), an area of high GR density. Therefore, glycine may very well have a role in the coding of nociceptive information. Finally, if glyci- 
nergic interneurons are associated with the polysegmental intrinsic analgesia system as defined by Basbaum and Fields (1978), then strychnine administration should produce hyperalgesia. In this regard, it is of interest to noie that humans suffering from strychnine toxicity complain of intense pain (Gaddum, 1959; Arena, 1979; Gosselin et al., 1976; Cushny, 1918; Clark, 1938). The pain is not part of the prodromal symptom complex (Gosselin et al., 1976; Arena, 1979; Cushny, 1918; Clark, 1938), i.e., is not spontaneous. Dusser de Barenne (1933) has reported that strychnine administration restricted to the dorsal horn of one spinal segment results in hyperalgesia of the skin in the "strychnine segment zone." These data favor an association of GRs with the polysegmental analgesia system. Interestingly, Basbaum and Fields (1978) have posited the existence of inhibitory interneurons in laminae I, II, and V which modulate a naloxone-insensitive component of nociceptive information.

The association of GRs with the acoustic system, an exteroceptive system, is also striking. The superior olivary nucleus and the nuclei of the lateral lemniscus, areas with high receptor density (Table II; M. A. Zarbin, J. K. Wamsley, and M. J. Kuhar, unpublished observations), are believed to have an important role in the localization of sound in space (Mountcastle, 1974; Goldstein, 1974). In this regard, it is of interest to note that humans suffering from strychnine toxicity commonly experience alterations in the acuity of auditory sensation (Gaddum, 1959; Arena, 1979; Gosselin et al., 1976; Cushny, 1918; Clark, 1938) as part of their prodromal symptom complex. This phenomenon is also observed with the administration of subconvulsive doses of strychnine (Cushny, 1918; Clark, 1938).

Areas of the CNS receiving significant amounts of nonnociceptive exteroceptive input from primary afferents, e.g., lamina IV of the spinal cord (Wall, 1967), the gracile and cuneate nuclei (Brodal, 1969), the analogous portions of the trigeminal nuclei, and the nucleus reticularis gigantocellularis (Brodal, 1969), had high densities of GRs. As in the case of audition, individuals suffering from strychnine toxicity frequently experience alterations in cutaneous sensation (Gaddum, 1959; Arena, 1979; Gosselin et al., 1976; Cushny, 1918; Clark, 1938) as part of the prodromal symptom complex. Similar alterations in sensation are reported by individuals consuming subconvulsive doses of strychnine (Cushny, 1918; Clark, 1938; Dusser de Barenne, 1933). Actually, Poulsson (1890) and, later, Dusser de Barenne (1933) showed that the alteration in cutaneous sensation is a necessary (but insufficient) condition for the convulsive effects of strychnine to occur.

The optic system (Brodal, 1969), a somatic afferent system, is associated with very low densities of GRs with the exception of the inner plexiform layer of the retina (J. K. Wamsley, J. M. Palacios, and M. J. Kuhar, submitted for publication). As Wamsley et al. (J. K. Wamsley, J. M. Palacios, and M. J. Kuhar, submitted for publication) point out, amacrine cells, interneurons which release glycine, have a role in modulating the discriminative aspects of vision. Moreover, individuals suffering from strychnine toxicity commonly report alterations in the acuity of visual perception (specifically, an enlargement of the visual field and enhanced color discrimination) as part of the prodromal symptom complex (Gaddum, 1959; Arena, 1979; Gosselin et al., 1976; Cushny, 1918; Clark, 1938). These alterations in sensation are also reported after administration of subconvulsive doses of strychnine (Cushny, 1918; Clark, 1938; Gaddum, 1959). It has been shown that strychnine exerts this effect by acting on the retina (Cushny, 1918; Clark, 1938; Gaddum, 1959).

The olfactory system (Brodal, 1969), like the optic system, has very low densities of GRs throughout all of its cortical components, including the olfactory tubercle. The olfactory bulb contained only very low densities of GRs (not shown).

Within the vestibular system, an area receiving somatic afferent input, the highest density of GRs was observed over the medial vestibular nucleus (vm). In previous communications (Palacios et al., 1981; Wamsley et al., $1980 \mathrm{~b}$ ), this laboratory has reported the existence of high densities of $\mathrm{H1}$-histamine and muscarinic cholinergic receptors in this locus. This has led to the suggestion (Palacios et al., 1981; Wamsley et al., 1980b) that vm is the site of action of some antimotion sickness drugs, such as antihistamines and anticholinergics. In this regard, it is interesting to note that consumption of subconvulsive doses of strychnine may result in a disturbance of equilibrium (Gosselin et al., 1976; Clark, 1938).

Regarding interoceptive afferents, neither special nor general visceral afferent "areas" in the brainstem, i.e., nts have significant densities of GRs.

Efferent areas. Efferent areas will now be considered. The data of Table II indicate a striking association of GRs with somatic and special visceral efferent areas. Cranial nerve nuclei III, IV, and VI are notable exceptions to this generalization.

In the category of general visceral efferent systems, the salivary and Edinger-Westphal nuclei contain low densities of GRs (M. A. Zarbin, J. K. Wamsley, and M. J. Kuhar, unpublished observations; Table II), while the dorsal motor nucleus of the vagus contains an extremely high density of GRs.

In the reticular formation, GRs are found in loci associated with cardiovascular (Milnor, 1974; Alexander, 1946) and respiratory (Lambertsen, 1974; Magoun and Rhines, 1946; Hugelin, 1980; Batsel, 1964) functions, suggesting that glycinergic neurons are involved in modulating these visceral activities. Pharmacologic and electrophysiologic data exist which support this notion. Feldberg and Guertzenstein (1976) have shown that, in cats, bilateral application of glycine to the ventral surface of the medulla (just caudal to the trapezoid body) results in profound hypotension. Cushny (1918) and Clark (1938) report that individuals suffering from strychnine overdose experience extreme hypertension (unrelated to the spasm of striated muscles, i.e., of central origin) and bradycardia. Strychnine administration to humans, in subconvulsive doses, has been shown to increase the respiratory rhythm (Remmers et al., 1980; Cushny, 1918; Clark, 1938). The data of Table II suggest that the cardiovascular and respiratory effects of glycine and strychnine may be mediated by GRs in the reticular formation. 
TABLE III

See text for discussion.

Postulated relationship between clinical effects of strychnine and areas with SBS

Clinical Effect of Strychnine

Heightened acuity of perception

a. Visual

b. Auditory

c. Cutaneous

d. Hyperalgesia and pain associated with convulsions
Locus of SBS

Retina (inner plexiform layer)

Superior olivary nucleus, nuclei of the lateral lemniscus

Dorsal horn of spinal cord, cuneate and gracile nuclei, and analogous portions of trigeminal nuclei

Dorsal horn of spinal cord (especially laminae II and V) and analogous portions of the trigeminal nuclei

Hyper-reflexia and muscular stiffness or spasm

a. Limb and trunk musculature

b. Muscles of mastication

c. Muscles of facial expression

Increased respiratory rate, bradycardia, and hypertension

Initiation of convulsions by visual and acoustic stimuli

Dorsal and ventral horns of spinal cord

Sensory and motor portions of trigeminal nuclei

Sensory portions of trigeminal nuclei and $n$ VII

Respiratory and cardiovascular centers in medulla and pons (npv, npd, rgi, nrp, rpc, and DMN of X)

Super colliculus (sgs, sgm, sgp)

\section{Strychnine receptors and myoclonic convulsions}

An attempt has been made to correlate, when possible, the location of SBS with clinical findings in strychnine toxicity. This correlation is, of course, somewhat speculative. Table III provides a general summary in which the symptoms of strychnine ingestion are associated with loci containing GRs and possibly mediating said symptoms. Certain aspects of strychnine-induced myoclonic convulsions will be considered now.

It is well known that visual or acoustic stimuli can initiate convulsions in humans suffering from strychnine toxicity (Gaddum, 1959; Arena 1979; Gosselin et al., 1976; Cushny, 1918; Clark, 1938). In cats, the superior colliculus is involved in the elaboration of motor responses to visual (so called "optic reflexes") and acoustic stimuli (Brodal, 1969; Ascher and Gachelin, 1967). The relatively high density of SBS observed in the cellular layers of this structure suggests that strychnine receptors in the superior colliculus may have a role in the initiation of convulsions by auditory or visual stimuli (in those suffering from strychnine toxicity). Ascher and Gachelin (1967) have provided data supporting this notion. They have shown that strychnine application to the superior colliculus results in the induction of myoclonic convulsions by either visual or auditory stimuli.

Dusser de Barenne (1933) has shown that the tetanic contractions observed in strychnine intoxication involve, ultimately, only intrinsic spinal mechanisms in order to become manifest. These contractions are noted only when both the dorsal and ventral horns are strychninized (Dusser de Barenne, 1933). As stated above, both loci are areas of very high SBS density, and strychnine probably exerts its effect on the spinal cord by interacting with these receptors.

An abstract of this work has appeared elsewhere (Zarbin et al., 1980).

\section{References}

Alexander, R. S. (1946) Tonic and reflex functions of medullary sympathetic cardiovascular centers. J. Neurophysiol. 9: 205217.

Alid, G., L. F. Valdes, and F. J. Orrego (1974) Strychnine as an anticholinesterase. In vitro studies with rat brain enzymes. Experientia 30: 266-268.

Altmann, H., G. ten Bruggencate, and U. Sonnhof (1972) Differential strength of action of glycine and GABA in hypoglossus nucleus. Pfluegers Arch. 331: 90-94.

Altmann, H., G. ten Bruggencate, U. Sonnhof, and R. Steinberg (1973) Action of gamma-aminobutyric acid and glycine on red nucleus neurones. Pfluegers Arch. 342: 283-288.

Altmann, H., G. ten Bruggencate, P. Pickelmann, and R. Steinberg (1976) Effects of GABA, glycine, picrotoxin and bicuculline methochloride on rubrospinal neurones in cats. Brain Res. 111: 337-345.

Aprison, M. H., and N. S. Nadi (1977) Glycine: Inhibition from the sacrum to the medulla. In Amino Acids as Chemical Transmillers, F. Fonmum, ed., pp. 531-570, Plenum Press, New York.

Aprison, M. H., and R. Werman (1965) The distribution of glycine in the cat spinal cord and roots. Life Sci. 4: 20752083.

Aprison, M. H., R. P. Shank, and R. A. Davidoff (1969) A comparison of the concentration of glycine, a transmitter suspect in different areas of the brain and spinal cord in seven different vertebrates. Comp. Biochem. Physiol. 28: 13451355.

Aprison, M. H., E. C. Daly, R. P. Shank, and W. J. McBride (1976) Neurochemical evidence for glycine as a transmitter and a model for its intrasynaptosomal compartmentation. In Metabolic Compartmentation and Neurotransmission, $\mathrm{S}$. Berl, D. D. Clarke, and D. Schneider, eds., pp. 37-63, Plenum Press, New York.

Apter, J. T. (1946) Eye movements following strychninization of the superior colliculus of cats. J. Neurophysiol. 9: 73-86.

Arena, J. M. (1979) Poisoning: Toxicology, Symptoms, Treatments, Ed. 4, pp. 177-179, Charles C Thomas, Springfield, IL. 
Arregui, A., W. J. Logan, J. P. Bennett, and S. H. Snyder (1972) Specific glycine-accumulating synaptosomes in the spinal cord of rats. Proc. Natl. Acad. Sci. U. S. A. 69: 3485-3489.

Ascher, P., and G. Gachelin (1967) Role du colliculus superieur dans l'elaboration de reponses motrices a des stimulations visuelles. Brain Res. 3: 327-342.

Basbaum, A. I., and H. L. Fields (1978) Endogenous pain control mechanisms: Review and hypothesis. Ann. Neurol. 4: 451462.

Batsel, H. L. (1964) Localization of bulbar respiratory center by microelectrode sounding. Exp. Neurol. 9: 410-426.

Battistin, L., A. Grynbaum, and A. Lajtha (1969) Distribution and uptake of amino acids in various regions of the cat brain in vitro. J. Neurochem. 16: 1459-1468.

Belcher, G., J. Davies, and R. W. Ryall (1976) Glycine mediated inhibitory transmission of group I-A excited inhibitory interneurons by Renshaw cells. J. Physiol. (Lond.) 256: 651-662.

Bhargava, V. K., and B. S. Meldrum (1969) The strychnine-like action of curare and related compounds on the somatosensory evoked response of the rat cortex. Br. J. Pharmacol. 37: 112122.

Brodal, A. (1969) Neurological Anatomy, pp. 56-57; 321-322; 338; 441-442; 462; 515. Oxford University Press, New York.

Brooks, V. B., and H. Asanuma (1965) Pharmacological studies of recurrent cortical inhibition and facilitation. Am. J. Physiol. 208: 674-681.

Caspary, D. M., D. C. Havey, and C. L. Faingold (1979) Effects of microiontophoretically applied glycine and GABA on neuronal response patterns in the cochlear nuclei. Brain Res. 172: 179-185.

Clark, A. J. (1938) Applied Pharmacology, Ed. 6, pp. 255-259, P. Blakiston's Son and Co., Inc., Philadelphia.

Crawford, J. M., R. D. Curtis, P. E. Voorhoeve, and V. J. Wilson (1963) Strychnine and cortical inhibition. Nature 200: $845-$ 846.

Creutzfeldt, O., G. Baumgartner, and L. Schoen (1956) Reaktion einzelner neurone des sensomotorischen cortex nach elektrischen. Reizen, I. (Hemmung und Erregung nach direkten und Kontralateralen Einzelreizen). Arch. Psychiatr. Nervenkr. 194: 597-619.

Crighel, E. (1966) The effects of GABA and strychnine on neocortical structures involved in the onset mechanism of epileptic activity. Epilepsia 7: 283-290.

Curtis, D. R., L. Hosli, and G. A. R. Johnston (1968) A pharmacological study of the depression of spinal neurons by glycine and related amino acids. Fxp. Brain Res. 6: 1-18.

Curtis, D. R., C. J. A. Game, D. Lodge, and R. M. McCulloch (1976) A pharmacological study of Renshaw cell inhibition. J. Physiol. (Lond.) 258: 227-242.

Cushny, A. R. (1918) A Textbook of Pharmacology and Therapeutics or The Action of Drugs, Ed. 7, pp. 271-281, Lea and Febiger, Philadelphia.

DeFeudis, F. V. (1977) Glycine receptors in the vertebrate central nervous system. Acta Physiol. Lat. Am. 27: 131-145.

Dusser de Barenne, J. G. (1933) The mode and site of action of strychnine on the nervous system. Physiol. Rev. 13: 325-335.

Ehinger, B., and B. Lindberg (1974) Light-evoked release of glycine from the retina. Nature 251: 727-728.

Feldberg, W., and P. G. Guertzenstein (1976) Vasodepressor effects obtained by drugs acting on the ventral surface of the brain stem. J. Physiol. (Lond.) 258: 337-355.

Felpel, L. P. (1972) Effects strychnine, bicuculline and picrotoxin on labyrinthine-evoked inhibition in neck motoneurons of the cat. Exp. Brain Res. 14: 494-502.

Felpel, L. P. (1977) Effects of strychnine, bicuculline and picrotoxin on inhibition of hypoglossal motoneurons. J. Neurosci. Res. 3: 289-294.

Freeman, A. R. (1973) Electrophysiological analysis of the actions of strychnine, bicuculline and picrotoxin on the axonal membrane. J. Neurobiol. 4: 565-582.

Gaddum, J. H. (1959) Pharmacology, Ed. 5, pp. 107-110, Oxford University Press, New York.

Galindo, A. (1969) GABA-picrotoxin interaction in the mammalian central nervous system. Brain Res. 14: 763-767.

Game, C. J. A., and D. Lodge (1975) The pharmacology of the inhibition of dorsal horn neurones by impulses in myelinated cutaneous afferents in the cat. Exp. Brain Res. 23: 75-84.

Glowinski, J. (1979) Some properties of the ascending dopaminergic pathways: Interactions of the nigrostriatal dopaminergic system with other neuronal pathways. In The Neurosciences: Fourth Study Program, F. O. Schmitt and F. G. Worden, eds., pp. 1069-1083, M. I. T. Press, Cambridge, MA.

Gogolak, G., S. Huck, P. Porges, and Ch. Stumpf (1974) Action of strychnine and central depressants on the cerebello-rubral system. Arch. Int. Pharmacodyn. Ther. 207: 322-332.

Goldstein, M. H., Jr. (1974) The auditory periphery. In Medical Physiology, V. B. Mountcastle, ed., Ed. 13, pp. 404-408, The C. V. Mosby Co., St. Louis, MO.

Gosselin, R. E., H. C. Hodge, R. P. Smith, and M. N. Gleason (1976) Clinical Toxicology of Commercial Products, Ed. 4, pp. 303-307, The Williams and Wilkins Co., Baltimore.

Haas, H. L., and L. Hosli (1973) Strychnine and inhibition of bulbar reticular neurones. Experientia 29: 542-544.

Headley, P. M., and D. Lodge (1976) Studies on field potentials and on single cells in the inferior olivary complex of the rat. Brain Res. 101: 445-459.

Hill, R. G., M. A. Simmonds, and D. W. Straugham (1976) Antagonism of gamma-aminobutyric acid by convulsants in the cuneate nucleus of the rat. Br. J. Pharmacol. 56: 9-19.

Hillman, P., and P. D. Wall (1969) Inhibitory and excitatory factors influencing the receptive field of lamina 5 spinal cord cells. Exp. Brain Res. 9: 284-306.

Hugelin, A. (1980) Does the respiratory rhythm originate from a reticular oscillator in the waking state? In The Reticular Formation Revisited: Specifying Function for a Nonspecific System, J. A. Hobson and M. A. B. Brazier, eds., p. 263, Raven Press, New York.

Ishida, Y. (1977) Intralaminar thalamic responses to somatic and fastigial stimulation: Cortical inhibition and its blockade by strychnine in cats. Neuropharmacology 16 : 163-170.

Ito, M. (1976) Roles of GABA neurons in integrated functions of the vertebrate CNS. In GABA in Nervous System Function, E. Roberts, T. N. Chase, and D. B. Tower, eds., pp. 427448, Raven Press, New York.

Kawamura, H., and L. Provini (1970) Depression of cerebellar Purkinje cells by microiontophoretic application of GABA and related amino acids. Brain Res. 24: 293-304.

Kelly, J. S., and K. Krnjevic (1968) Effects of gamma-aminobutyric acid and glycine on cortical neurones. Nature 219: 1380-1381.

Kelly, J. S., and K. Krnjevic (1969) The action of glycine on cortical neurones. Exp. Brain Res. 9: 155-163.

Kelly, J. S., and L. P. Renaud (1973) On the pharmacology of the glycine receptors on the cuneothalamic relay cells in the cat. Br. J. Pharmacol. 48: 387-395.

Kiczka, K., H. Kuleszko-Kopystecka, and B. Bilinska (1977) Effects of strychnine and picrotoxin on the activity of laryngeal and phrenic motoneurons during stimulation of the vagus nerve. Acta Physiol. Pol. 28: 1-11.

Kidokoro, Y., K. Kubota, S. Shuto, and R. Sumino (1968) Reflex organization of cat masticatory muscles. J. Neurophysiol. 31: 695-708.

Kier, L. B., A. Al-Shamma, D. Campbel, P. N. Patil, and A. Tye (1966) Presynaptic inhibition in primate lateral geniculate nucleus. Nature 210: 740-742.

Konig, J. F. R., and R. A. Klippel (1963) The Rat Brain: A 
Stereotaxic Atlas, Robert E. Krieger Publishing Co., Inc., Huntington, New York.

Krnjevic, K., M. Randic, and D. W. Straughan (1966) Pharmacology of cortical inhibition. J. Physiol. (Lond.) 184: 78105.

Lambertsen, C. J. (1974) Neurogenic factors in control of respiration. In Medical Physiology, V. B. Mountcastle, ed., Ed. 13, p. 1440, The C. V. Mosby Co., St. Louis, MO.

Lodge, D., D. R. Curtis, and S. J. Brand (1977) A pharmacological study of the inhibition of ventral group I-a exited spinal interneurones. Exp. Brain Res. 29: 97-105.

Logan, W. J., and S. H. Snyder (1972) High affinity uptake systems for glycine, glutamic and aspartic acids in synaptosomes of rat central nervous tissues. Brain Res. 42: 413-431.

Magoun, H. W., and R. Rhines (1946) An inhibitory mechanism in the bulbar reticular formation. J. Neurophysiol 9: 165-171.

Matus, A. I., and M. E. Dennison (1971) Autoradiographic localization of tritiated glycine at 'flat-vesicle' synapses in spinal cord. Brain Res. 32: 195-197.

Milnor, W. R. (1974) The cardiovascular control system. In Medical Physiology, V. B. Mountcastle, ed., Ed. 13, pp. 958983, The C. V. Mosby Co., St. Louis, MO.

Morimoto, T., M. Takata, and Y. Kawamura (1968) Effect of lingual nerve stimulation on hypoglossal motoneurons. Exp. Neurol. 22: 174-190.

Mountcastle, V. B. (1974) Central neural mechanisms in hearing. In Medical Physiology, V. B. Mountcastle, ed., Ed. 13, pp. 424-430, The C. V. Mosby Co., St. Louis, MO.

Muller, W. E., and S. H. Snyder (1978) Strychnine binding associated with synaptic glycine receptors in rat spinal cord membranes: Ionic influences. Brain Res. 147: 107-116.

Palacios, J. M., W. S. Young, III, and M. J. Kuhar (1980) Autoradiographic localization of gamma-aminobutyric acid (GABA) receptors in the rat cerebellum. Proc. Natl. Acad. Sci. U. S. A. 77: 670-674.

Palacios, J. M., J. K. Wamsley, and M. J. Kuhar (1981) The distribution of histamine $\mathrm{Hl}$ receptors in the rat brain: An autoradiographic study. Neuroscience 6: 15-37.

Poulsson, E. (1890) Ueber die lahmende Wirkung des Strychnins. Arch. Exper. Path. Pharmak. 26: 22-38.

Price, D. I., A. Stocks, J. W. Griffin, A. Young, and K. Peck (1976) Glycine specific synapses in rat spinal cord: Identification by electron microscopic autoradiography. J. Cell Biol. 68: 389-395.

Rayport, M., and H. Jasper (1958) Microelectrode analysis of the cortical strychnine spike. Electroencephologr. Clin. Neurophysiol. 10: 764 .

Remmers, J. E., A. M. Anch, and W. J. deGroot (1980) Amelioration of upper airway obstruction during sleep by strychnine. Clin. Res. 28: 531A.

Ribeiro-da-silva, A., and A. Coimbra (1980) Neuronal uptake of ${ }^{3} \mathrm{H}-\mathrm{GABA}$ and ${ }^{3} \mathrm{H}$-glycine in laminae I-III (substantia gelatinosa rolandi) of the rat spinal cord. An autoradiographic study. Brain Res. 188: 449-464.

Roberts, P. J. (1974) The release of amino acids with proposed neurotransmitter function from the cuneate and the gracile nuclei of the rat in vivo. Brain Res. 67: 419-428.

Rotter, A., N. J. M. Birdsall, P. M. Field, and G. Raisman
(1979) Muscarinic receptors in the central nervous system of the rat. II. Distribution of binding of $\left[{ }^{3} \mathrm{H}\right]$ propyl-benzylcholine mustard in the midbrain and hindbrain. Brain Res. Rev. 1: 167-183.

Tebecis, A. K. (1973) Transmitters and reticulospinal neurons. Exp. Neurol. 40: 297-308.

Tebecis, A. K., and A. DiMaria (1972) Strychnine-sensitive inhibition in the medullary reticular formation: Evidence for glycine as an inhibitory transmitter. Brain Res. 40: 373-383.

Wall, P. D. (1967) The laminar organization of dorsal horn and effects of descending impulses. J. Physiol. (Lond.) 188: 403423.

Wall, P. D., and N. H. Horwitz (1951) Observations on the physiological actions of strychnine. J. Neurophysiol. 14: 255263.

Wamsley, J. K., M. A. Zarbin, N. J. M. Birdsall, and M. J. Kuhar (1980a) Muscarinic cholinergic receptors: Autoradiographic localization of high and low affinity agonist binding sites. Brain Res. 200: 1-12.

Wamsley, J. K., M. S. Lewis, W. S. Young, III, and M. J. Kuhar (1980b) Autoradiographic localization of muscarinic cholinergic receptors in rat brainstem. J. Neurosci. 1: 176-191.

Werman, R., R. A. Davidoff, and M. H. Aprison (1966) Glycine and postsynaptic inhibition in the cat spinal cord. Physiologist 9: 318 .

Werman, R., R. A. Davidoff, and M. II. Aprison (1967) Inhibition of motoneurones by iontophoresis of glycine. Nature 214 : 681-683.

Werman, R., R. A. Davidoff, and M. H. Aprison (1968) Inhibitory action of glycine on spinal neurons in the cat. J. Neurophysiol. 31: 81-95.

Yokota, T., N. Nishikawa, and Y. Nishikawa (1979) Effects of strychnine upon different classes of trigeminal subnucleus caudalis neurons. Brain Res. 168: 430-434.

Young, A. B., and S. H. Snyder (1973) Strychnine binding associated with glycine receptors of the central nervous system. Proc. Natl. Acad. Sci. U. S. A. 70: 2832-2836.

Young, A. B., and S. H. Snyder (1974a) Strychnine binding in rat spinal cord membranes associated with the synaptic glycine receptor: Cooperativity of glycine interactions. Mol. Pharmacol. 10: 790-809.

Young, A. B., and S. H. Snyder (1974b) The glycine synaptic receptor: Evidence that strychnine binding is associated with the ionic conductance mechanism. Proc. Natl. Acad. Sci. U. S. A. 71: 4002-4005.

Young, W. S., III, and M. J. Kuhar (1979a) A new method for receptor autoradiography: $\left[{ }^{3} \mathrm{H}\right]$ Opioid receptors in rat brain. Brain Res. 179: 255-270.

Young, W. S., III, and M. J. Kuhar (1979b) Autoradiographic localization of benzodiazepine receptors in the brains of humans and animals. Nature 280: 393-395.

Young, W. S., III, and M. J. Kuhar (1980) Radiohistochemical localization of benzodiazepine receptors in rat brain. J. Pharmacol. Exp. Ther. 212: 337-346.

Zarbin, M. A., J. K. Wamsley, and M. J. Kuhar (1980) Glycine receptor localization in rat brain histochemical methods. Soc. Neurosci. Abstr. 6: 359. 